\title{
THE E-LEARNING UTILIZATION ON ATTITUDES AND BEHAVIOR OF DIARRHEA PREVENTION DURING PANDEMIC
}

\author{
Zul Fikar Ahmad ${ }^{1 *}$, Ardiansyah², Siti Surya Indah Nurdin ${ }^{3}$ \\ ${ }^{1}$ Public Health Department, Health and Sport Faculty, Gorontalo State University. \\ ${ }^{2}$ Economics Education Department, Economics Faculty, Gorontalo State University. \\ ${ }^{3}$ Midwifery Department, Health Sciences Faculty, Muhammadiyah Gorontalo University. \\ *e-mail: zulfikar@ung.ac.id
}

Article History:Received:11 november 2020; Accepted: 27 December 2020; Published online: 05 April 2021

ABSTRACT : Diarrhoea is a health problem that is often experienced by infants and toddlers and in almost every country. One of the efforts to prevent diarrhoea was through counselling. Due to the pandemic situation, face-to-face counselling was not possible. This study aimed to assess the use of e-learning in increasing knowledge, attitudes, and behaviours to prevent diarrhoea. This research was an analytical observational study with the design of The One Group Pre-test Post-test Design. Samples were select used the purposive sampling technique. The sample size in this study was 54 students. The eLearning model used in this research was Google Class. The data were obtained by using google form then analyzed using McNemar Test. The results of the analysis showed that there were differences in knowledge ( $\mathrm{p}$-value $=0.000)$, attitudes $(\mathrm{p}$-value $=0.031)$, and behaviour ( $\mathrm{p}$-value $=0.016$ ) to prevent diarrhea before and after treatment. The utilization of online learning (elearning) significantly affected increasing knowledge, attitudes, and behaviour in preventing diarrhea. In the future, e-learning can be an alternative to prevent diarrhea during a pandemic.

Keywords: Diarrhea; E-learning; Prevention

\section{BACKGROUND}

Diarrhoea is still a health problem experienced by infants and toddlers in almost every country. Infants and toddlers suffering from diarrhea are still significant public health problems since they are the third major contributor to children's morbidity and mortality rates in various developing countries (Mufidah, 2012).

Khalil et al. (2016) estimated more than 125.000 mortality of diarrheal cases $(3.6 \%$ of total mortality) in 2013, mostly in low and middle-income countries. Based on primary health research results in 2018 , the prevalence of diarrhoea in Indonesia was $6.8 \%$. The prevalence of diarrhoea in Gorontalo Province was already below the national average (6.4\%). However, it still needs more effort because diarrhoea continues to cause death and causes Extraordinary Events in various regions in Gorontalo Province.

The results of Integrated Surveillance and $K L B$ of the Gorontalo Province Health Office show that diarrhea was a disease with the highest number of cases and has become an outbreak in 2019 with 9273 cases. Boalemo Regency was the area with the highest cases, 1552 cases; 3 of them died.

Diarrhea could be caused by a lack of hygiene habits (Grafika et al., 2018), education level, and improper toilet (Andik, 2019). Another factor increasing the risk of diarrhea is exclusive breastfeeding, where toddlers who are not given exclusive breastfeeding suffer more from diarrhea, less use of health services, and inappropriate parenting styles (Dhiana et al., 2017).

Preventive steps to prevent morbidity and mortality due to diarrheal diseases are increasing household access to clean and healthy water, improve home sanitation, and improve personal hygiene for all family members (Black and Walker 2019). The next step is breastfeeding, giving nutrients-rich food, and using the proper toilet (Grafika et al., 2018). In some areas of sub-Saharan Africa, toddlers are vaccinated to prevent diarrhea. This is estimated to prevent more than 28,000 deaths due to diarrhea in toddlers (Troeger et al., 2018).

Another preventive effort that is often carried out is by providing health education. This impacts increasing knowledge, attitudes, and preventive behaviors against diarrhea (Pratiwi et al., 2016). The extension could change people's behavior in understanding the importance of a clean environment to be free from disease. It is considered to reduce diarrhea cases (Gunawan, 2018).

The methods and media used in health education are crucial to conveying the messages clearly, and targeted communities can receive these messages clearly and precisely (Notoadmodjo 2010b). However, the facts show that the current health education methods are no longer appropriate because there are still outbreaks and deaths due to diarrhea. It is necessary to find other alternative methods that may be more effective in increasing knowledge, attitudes, and behaviors to prevent diarrhea disease besides the conventional extension methods used so far.

Primary school students were selected to be the sample since they and the toddlers were the most vulnerably suffered from diarrhea due to their weak body years (Widoyono 2011). They are prone to diarrhea

*Corresponding author: Zul Fikar Ahmad

Public Health Department, Health and Sport Faculty, Gorontalo State University.

e-mail: zulfikar@ung.ac.id 
because most of them behave at risk of diarrhea, such as not washing their hands before eating and after defecating and carelessly snacking. Therefore, it is essential to assess E-learning's influence in increasing knowledge, attitudes, and behavior of diarrhea prevention.

\section{RESEARCH METHOD}

This research was a Quasi-Experimental study using The One Group Pre-test Post-test Design. The study population was all elementary school students in Boalemo Regency. The research sample was selected from several classes implementing online learning. Samples were selected using the purposive sampling technique. The sample size in this study was 54 students.

E-learning used in this study was the same as e-learning used by schools: Google Class. The extension materials were made in reading completed with pictures and videos containing knowledge about attitudes and behaviors in preventing diarrhea.

The data were collected using Google Form, which was uploaded in Google Class. The test was started with a pre-test. Then, the material was given to be studied and understood for one week. Furthermore, the post-test was carried out with the same questions as the pre-test. Univariate data analysis was used to assess the frequency distribution of respondents. Then, the McNemar Test analysis was carried out to assess changes in the level of knowledge, attitudes, and behavior in preventing diarrhea before and after treatment.

\section{RESULT AND DISCUSSION}

1. Result

a. Respondent General Characteristics

Table 1

Respondent General Characteristics

\begin{tabular}{|c|c|c|}
\hline Characteristic & $\mathbf{n}$ & $\%$ \\
\hline \multicolumn{3}{|l|}{ Gender } \\
\hline Male & 27 & 50 \\
\hline Female & 27 & 50 \\
\hline \multicolumn{3}{|l|}{ Age (year) } \\
\hline 8 & 20 & 37 \\
\hline 9 & 19 & 35,2 \\
\hline 10 & 14 & 25,9 \\
\hline 11 & 1 & 1,9 \\
\hline \multicolumn{3}{|l|}{ Grade } \\
\hline III & 29 & 53,7 \\
\hline IV & 25 & 46,3 \\
\hline
\end{tabular}

The results showed that male and female respondents have the same frequency distribution. Respondents aged eight years were the respondents with the highest distribution, and respondents aged 11 years were the respondents with the lowest distribution. Grade III respondents were higher than grade IV respondents.

\section{Knowledge, Attitude, and Behavior before Treatment.}

Before the treatment, respondents with medium knowledge had the highest frequency distribution. A respondent with a positive attitude is more significant than a negative attitude respondent. Otherwise, Respondents with bad diarrhea prevention behavior were more than good prevention behavior. The frequency distribution of respondents based on knowledge, attitudes, and behavior before treatment is shown in Table 2.

Table 2

Knowledge, Attitude, and Behavior before Treatment

\begin{tabular}{ccc}
\hline Variable & n & \% \\
\hline Knowledge & & \\
High & 21 & 38,9 \\
Medium & 26 & 48,1 \\
Low & 7 & 13,0 \\
\hline Attitude & & \\
Positive & 40 & 74,1 \\
Negative & 14 & 25,9 \\
\hline Behaviour & & \\
Good & 26 & 48,1
\end{tabular}




\begin{tabular}{rcc}
\hline Variable & n & \% \\
\hline Bad & 28 & 51,9 \\
\hline & \multicolumn{3}{c}{ Source: Primer Data, 2020 }
\end{tabular}

3. Knowledge, Attitude, and Behavior after Treatment.

Table 3

Knowledge, Attitude, and Behavior after Treatment.

\begin{tabular}{ccc}
\hline \multirow{2}{*}{ Variable } & \multicolumn{2}{c}{ After } \\
\cline { 2 - 3 } & $\mathbf{N}$ & $\mathbf{\%}$ \\
\hline Knowledge & & \\
High & 27 & 50 \\
Medium & 27 & 50 \\
Low & 0 & 0 \\
\hline Attitude & & \\
Positive & 46 & 85,2 \\
Negative & 8 & 14,8 \\
\hline Behaviour & & \\
Good & 33 & 61,1 \\
Bad & 21 & 38,9 \\
\hline
\end{tabular}

After treatment, there were no respondents found in the low knowledge category. Respondents with high and medium knowledge had the same frequency distribution. Positive attitudes towards diarrhea prevention were higher than respondents who had negative attitudes. Respondents who have diarrhea prevention behavior were higher than those who had bad behavior.

d. Knowledge, Attitude, and Behavior Difference After and Before Treatment.

Tabel 4

Knowledge, Attitude, and Behavior Difference After and Before Treatment.

\begin{tabular}{lccccc}
\hline \multirow{2}{*}{ Variable } & \multicolumn{2}{c}{ Before } & \multicolumn{2}{c}{ After } & $\begin{array}{c}p- \\
\text { value }\end{array}$ \\
\cline { 2 - 5 } & $\mathbf{n}$ & $\mathbf{\%}$ & $\mathbf{N}$ & $\mathbf{\%}$ & \\
\hline Knowledge & & & & & \\
$\quad$ High & 21 & 38,9 & 27 & 50 & 0,000 \\
$\quad$ Medium & 26 & 48,1 & 27 & 50 & \\
$\quad$ Low & 7 & 13,0 & 0 & 0 & \\
\hline Attitude & & & & & \\
$\quad$ Positive & 40 & 74,1 & 46 & 85,2 & 0,031 \\
$\quad$ Negative & 14 & 25,9 & 8 & 14,8 & \\
\hline Behavior & & & & & \\
$\quad$ Good & 26 & 48,1 & 33 & 61,1 & 0,016 \\
Bad & 28 & 51,9 & 21 & 38,9 & \\
\hline
\end{tabular}

Source: Primer Data, 2020

The results showed differences in students' knowledge before and after counseling through online learning with $\mathrm{p}=0.000$. The distribution of respondents with high knowledge increased after treatment from $38.9 \%$ to $50 \%$. Based on the respondents 'attitudes, it was found that there were differences in respondents' attitudes towards diarrhea prevention before and after online learning about diarrhea. This is indicated by the $p$ number, which was 0.031 . The respondents who had a positive attitude increased after treatment, which was $74.1 \%$ to $85.2 \%$.

Diarrhea prevention behavior before and after treatment through learning had a difference with a pvalue $=0.016$. This showed that there was an effect of counselling through online learning in improving diarrhea prevention behavior. The respondent's good behavior also increased from the previous $48.1 \%$ to $61.1 \%$ after the treatment.

\section{B. Discussion}

This study discusses the effect of extension methods on knowledge and behavioral attitudes in preventing diarrhea. The analysis results with statistical tests show that there is a relationship between knowledge and attitudes in efforts to prevent diarrhea in primary school students. Other studies show that there 
were significant differences before and after the intervention. Also, the development of the CBIA-Diarrhea module drives the increase of knowledge, attitudes, and behavior have increased after intervention with the CBIA-Diarrhea method. The development of CBIA to become CBIA-Diarrhea was proven to increase mothers' knowledge, attitudes, and behavior in managing diarrhea (Kumala and Suryawati 2016). Other research in Majalengka showed that health education could improve knowledge, attitudes, and behaviors to prevent diarrhea (Norviatin and Adiguna 2017).

The results of the distribution of respondents with high knowledge increased after treatment from $38.9 \%$ to $50 \%$. This is because the information made in the e-module and learning videos on preventing diarrhea allowed them to get information about diarrhea prevention in different ways, making them get new things about diarrhea prevention. Research on audio-visual counseling in diarrhea counseling showed a significant effect in increasing knowledge, attitudes, and behaviors for preventing diarrhea (Rianti, Apriliawati, and Sulaiman 2020).

This is in line with Notoatmodjo's (2010) theory stating that knowledge is the result of knowing and knowledge occurring after people sense a particular object; in most people, knowledge is obtained through the vision, hearing, and their environments.

The respondent's efforts to obtain information or lessons directly from the health team or the school regarding the prevention of diarrhea increased their level of knowledge. It is related to the condition before treatment where there was a low knowledge level in seven respondents (13\%), and it is strongly decreased after the treatment $(0 \%)$.

In every individual who learns both actual and potential, the change occurs because of an effort, not the maturity process. Learning is a process of changing activities and reactions to the environment, where these changes cannot be called learning when they are caused by growth. So that without learning or accurate information from someone or the media, it will not make a change.

According to Natoatmodjo (2012), the environment affects the process of transfer knowledge into individuals who are in the environment. This happens because there is a reciprocal interaction or not, which will be responded to as knowledge by each respondent. Information/mass media can also influence respondents' knowledge in this study where the mass media carry messages containing suggestions that can direct people's opinion. The existence of new information about something provides a new basic cognitive about it. The information in this study is about preventing diarrhea.

Based on the respondents' attitudes, it was found that there were differences in respondents' attitudes towards diarrhea prevention before and after online learning about diarrhea. The analysis results showed that there was an effect of counseling through e-learning media on attitudes to preventing diarrhea.

The process of habitual attitudes can occur because of stimulation. In this study, the stimulus refers to providing video interventions and learning modules on diarrhea prevention. The stimulus stimulates the respondent's self to respond in the form of positive and negative attitudes, which eventually manifest in behavior or action. This increasing attitude cannot be separated from several factors: personal experiences, the dominant people's influence, and the education obtained (Azwar, 2007).

Based on the respondents' attitudes, it was found that there were differences in respondents' attitudes towards diarrhea prevention before and after online learning about diarrhea. The distribution of respondents who had a positive attitude increased after treatment, from $74.1 \%$ to $85.2 \%$. The results obtained are in line with research in Batam, which found that extension media extension could increase knowledge and attitudes in preventing diarrhea (Esmeralda 2020). Other studies have shown that there was a significant relationship between the knowledge, attitudes, and behavior of mothers regarding the STBM program toward diarrhea cases (Fajrin, 2013).

Attitude is a person's closed response to a specific stimulus or object, involving opinion and emotional factors such as pleasure, displeasure, agreement, disagreement, reasonable, and wrong. In determining a complete attitude, the components of knowledge, ways of thinking, beliefs, and emotions play an essential role. Knowledge makes a person think, then beliefs and emotions work to create an attitude (Notoadmodjo, 2010).

Attitudes cannot be immediately seen but can only be interpreted from some closed behaviors. Students' attitudes include accepting, responding to, appreciating, and being responsible for preventing diarrhea. A good student attitude will influence the students themselves in preventing diarrhea.

The diarrhea prevention behavior before and after treatment through online learning has a difference with a p-value $=0.016$. This shows that there is an effect of counseling through online learning on improving diarrhea prevention behavior. The respondent's good behavior also increased from the previous: $48.1 \%$ to $61.1 \%$ after treatment. This is in line with research Norviatin \& Adiguna (2016), which states that the level of knowledge, behavior, and attitudes of mothers about diarrhea in toddlers has experienced significant changes after counselling, where the knowledge, behavior, and attitudes of mothers are getting better after an extension on diarrhea prevention.

The behavior has a direct impact on changing health indicators. In theory, it is stated that health status is influenced by four main factors: behavior, environment, health services, and heredity. In health promotion, behavior change can be pursued through communication or counselling (predisposing factors: knowledge, 
attitudes, value traditions, Etc.), community empowerment (enabling factors, the availability of resources or facilities), and training (reinforcing factors, attitudes, and behavior of health workers). There was an increase in respondents' knowledge and attitudes about preventing diarrhea and a change in respondent behavior regarding diarrhea prevention.

Another in-line research conducted by Arwani et al. (2012) found a relationship between attitudes and behavior of toddlers mothers in the prevention of diarrhea disease $(\mathrm{p}=0.000)$. The better the mothers' attitude, the better behavior they would be in preventing diarrhea $(r=0.373)$. Other research showed that there was an effect of video viewing interventions on knowledge, attitudes, and actions about diarrhea in students in Bali (Nuadi et al., 2020)

From the results of this study, better behavior changes are expected to reduce the diarrhea case. Also, it is hoped a significant role from mothers in educating their children. Research showed that maternal parenting affected children's growth and development (Nurdin, Katili, and Ahmad 2019) in preventing diarrhea (Fatmawati 2018).

\section{CONCLUSION}

Based on the results and discussion, it can be concluded that the use of online learning (e-learning) using learning media (videos and e-modules) has a significant effect on increasing knowledge, attitudes, and behavior in preventing diarrhea. In the future, counselling using e-learning can be an alternative to prevent diarrhea during the pandemic. It can raise awareness in the family or community about the importance of efforts to prevent diarrhea and provide help either independently or by utilizing the available health service facilities.

\section{REFERENCES}

Ajeng Padma Kumala, Sri Suryawati (2016). CBIA-Diare Untuk Meningkatkan Pengetahuan, Sikap Dan Perilaku Ibu Dalam Tatalaksana Diare Pada Balita Di Bina Keluarga Balita (BKB) Desa Banguntapan Kabupaten Bantul. Majalah Farmaseutik, Vol. 12 No. 1 Tahun 2016

Andik Setiyono. 2019. "Faktor Risiko Kejadian Diare Pada Masyarakat Kota Tasikmalaya." Jurnal Kesehatan Komunitas Indonesia 15(2): 49-59.

Arianti Miranti Lestari Fajrin. 2013. Hubungan antara Pengetahuan, Sikap, dan Perilaku Ibu Mengenai Program Sanitasi Total Berbasis Masyarakat terhadap Kejadian Diare pada Balita di Kelurahan Siantan Tengah. Jurnal Mahasiswa Fakultas Kedokteran Untan.

Arwani, Dwi Retnaningsih, Mashuri. 2012. Hubungan antara tingkat pendidikan, pengetahuan, sikap dengan Perilaku ibu balita dalam pencegahan penyakit diare di puskesmas Bancak kabupaten semarang. Jurnal Ilmu dan Teknologi Kesehatan, Vol 3 No.1 Juli 2012. ISSN 20868510

Azwar, S. 2007, Sikap Manusia dan pengukurannya, Edisi 2, Pustaka Pelajar, Yogyakarta, PP 3-5, 14-16

Black, Robert E, and Christa Fischer Walker. 2019. "Do Water, Sanitation, and Hygiene Interventions Prevent Childhood Diarrhea?" The journal of infectious diseases.

Dhiana, Wiwin Rahma, Retno Hestiningsih, and Sri Yuliawati. 2017. "Faktor Risiko Pola Asuh Terhadap Kejadian Diare Bayi (0-12 Bulan) Di Wilayah Kerja Puskesmas Kedungmundu Kecamatan Tembalang Kota Semarang." Jurnal Kesehatan Masyarakat (e-Journal) 5(4): 525-32.

Dini Norviatin, Teguh Yudha Adiguna 2016. Pengaruh Penyuluhan dan Pemberian Leaflet terhadap Peningkatan Pengetahuan, Perilaku, dan Sikap Ibu Tentang Diare pada Balita di Puskesmas Maja Kabupaten Majalengka. Tunas Medika Jurnal Kedokteran \& Kesehatan. Vol 3, No 4 (2016)

Esmeralda, Nopri. 2020. "Pengaruh Media Penyuluhan Terhadap Pengetahuan Dan Sikap Ibu Tentang Diare Pada Anak Di Puskesmas Batu Aji Kota Batam 2018." Zona Kedokteran: Program Studi Pendidikan Dokter Universitas Batam 9(2):53-61.

Fatmawati, Tina Yuli. 2018. "Peran Ibu Dalam Upaya Pencegahan Diare Pada Balita Di Kelurahan Kenali Asam Bawah.” Jurnal Akademika Baiturrahim Jambi 6(1):58-63.

Grafika, Dewi, Yusuf Sabilu, and Sabril Munandar. 2018. "Faktor Risiko Kurangnya Perilaku Hidup Bersih Dan Sehat (PHBS) Tatanan Rumah Tangga Terhadap Kejadian Diare Pada Balita Di Wilayah Kerja Puskesmas Benu-Benua Kota Kendari Tahun 2017.” (Jurnal Ilmiah Mahasiswa Kesehatan Masyarakat) 2(7).

Gunawan, Dahlan. 2018. "Pengaruh Media Penyuluhan Terhadap Pengetahuan Dan Sikap Ibu Tentang Diare Pada Anak Di Puskesmas Batu Aji, Kota Batam.” Jurnal Kedokteran Nanggroe Medika 1(2): 10-16.

Kemenkes. 2011a. Panduan Sosialisasi Tatalaksana Diare Balita. Jakarta: Kementrian Kesehatan Republik Indonesia, Direktorat Jenderal Pengendalian Penyakit dan Penyehatan Lingkungan. 
. 2011b. Situasi Diare Di Indonesia. Jakarta: Pusat Data dan Informasi Kesehatan Kementrian Kesehatan RI.

. 2018. Laporan Nasional Riset Kesehatan Dasar Tahun 2018. Jakarta: Kementrian Kesehatan Republik Indonesia.

Khalil, Ibrahim, et al. 2016. "Burden of Diarrhea in the Eastern Mediterranean Region, 1990-2013: Findings from the Global Burden of Disease Study 2013." The American journal of tropical medicine and hygiene 95(6): 1319-29.

Kumala, Ajeng Padma, and Sri Suryawati. 2016. “Cbia-Diare Untuk Meningkatkan Pengetahuan, Sikap Dan Perilaku Ibu Dalam Tatalaksana Diare Pada Balita Di Bina Keluarga Balita (BKB) Desa Banguntapan Kabupaten Bantul." Majalah Farmaseutik 12(1):390-93.

Mufidah, Fatchul. 2012. Ermati Penyakit-Penyakit Yang Rentan Diderita Anak Usia Sekolah. Yogyakarta: FlashBooks.

Notoadmodjo, Soekidjo. 2010a. Ilmu Perilaku Kesehatan. Jakarta: Rineka Cipta.

_. 2010b. Promosi Kesehatan Dan Ilmu Perilaku. Jakarta: Rineka Cipta.

Natoatmodjo, S. 2012. Promosi Kesehatan dan perilaku Kesehatan. Jakarta. Penerbit Rineka Cipta pp. 134-143

Norviatin, Dini, and Teguh Yudha Adiguna. 2017. "Pengaruh Penyuluhan Dan Pemberian Leaflet Terhadap Peningkatan Pengetahuan, Perilaku, Dan Sikap Ibu Tentang Diare Pada Balita Di Puskesmas Maja Kabupaten Majalengka." Tunas Medika Jurnal Kedokteran \& Kesehatan 3(4).

Nuadi, Ananda Gusti, S. K. M. Sali, I. Wayan, S. K. M. Mahayana, and I. Made Bulda. 2020. "Pengaruh Intervensi Penayangan Video Terhadap Pengetahuan Sikap Dan Tindakan Tentang Penyakit Diare Siswa Sekolah Dasar Tahun 2020.”

Nurdin, Siti Surya Indah, Dwi Nur Octaviani Katili, and Zul Fikar Ahmad. 2019. "Faktor Ibu, Pola Asuh Anak, Dan MPASI Terhadap Kejadian Stunting Di Kabupaten Gorontalo.” Jurnal Riset Kebidanan Indonesia 3(2):74-81.

Pratiwi, Dita Anugrah, Nani Yuniar, and Putu Eka Meiyana Erawan. 2016. "Pengaruh Penyuluhan Metode Permainan Edukatif Dan Metode Ceramah Terhadap Pengetahuan, Sikap Dan Tindakan Tentang Pencegahan Penyakit Diare Pada Murid SD Di Kecamatan Poasia Kota Kendari Tahun 2015.” (Jurnal Ilmiah Mahasiswa Kesehatan Masyarakat) 1(2).

Rianti, Rianti, Anita Apriliawati, and Suhendar Sulaiman. 2020. "Pengaruh Edukasi Menggunakan Leaflet, Audio Visual, Leaflet Dan Audio Visualterhadap Pengetahuan, Sikap Dan Perilaku Orangtua Dalam Pencegahan Diare Di Puskesmas Rawat Inap Manis Jaya Tangerang.” Journal of Islamic Nursing 5(1):6067.

Sopiyudin, Dahlan M. 2013. Besar Sampel Dan Cara Pengambilan Sampel Dalam Praktik Penelitian Kedokteran Dan Kesehatan. Jakarta: Salemba Medika.

Troeger, Christopher et al. 2018. "Rotavirus Vaccination and the Global Burden of Rotavirus Diarrhea Among Children Younger Than 5 Years." JAMA Pediatrics 172(10): 958-65. https://doi.org/10.1001/jamapediatrics.2018.1960.

Widoyono. 2011. Penyakit Tropis: Epidemiologi, Penularan Pencegahan, Dan Pemberantasan. Jakarta: Erlangga. 